\title{
USING TICKING OFF ITEMS TECHNIQUE IN THE TEACHING LISTENING SKILL AT ELEMENTARY STUDENT
} (Penggunaan Teknik “Ticking Off Items” Dalam Pengajaran Keterampilan
Menyimak Di Sekolah Dasar)

\author{
Fitri Annisa \\ Program Studi PGMI IAILM Suryalaya \\ fitriannisa@gmail.com
}

\begin{abstract}
Listening skill is the first skill that should be mastered by young learners when they learn language besides speaking, reading and writing skill. English in In Indonesia is still considered as difficult subject at school. Especially in listening, most of student especially young learners get difficulties to comprehend what is spoken in English. It is natural thing when they do not comprehend because English is a foreign language. English course, whether as a local conten, a compulsary or an extra-curicullar subject at elementary School, is given to equip students with English so they an enhance communicative competence in language accompaniying action on a simple basis in the context of school and give awareness the importance of English language to improve competitiveness in a global society. Most of elementary school dont have any tape recorder yet, which contain English speaking by native language or the expert of English language. Thus, EYL teachers have important role as the sources of teaching and learning. This is because the students are able to listen the teacher's talk directly. In addition, teacher should be more creative teaching listening to young learners, in other the students are not boring.
\end{abstract}

Key Words: Thinking, Listening Skill, Elementary School

\section{BACKGROUND}

In the globalization era, English is widely regarded the first international language. The importance of English language is happened In Indonesia. A number of people learning English. Many of education level both local and international standard (kindergarten, elementary school, secondary, tertiary and university level) implement English instruction. The policy of English instruction in elementary school has been many changes. Rahmajanti (2008) states that In Indonesia, in particular, the inclusion of English instruction as a local content subject in the elementary school curriculum has been legalized by the Decree of the Minister of Education and Culture No. 060/U/1993 and the Decree of the Provincial Department Education and Culture, East Java, No. 1702/104/M/94 SK. With the publication of the decree, a lot of elementary schools competed to implement the English instruction at their schools without considering

Diterima: Januari 2018. Disetujui: Pebruari 2018. Dipublikasikan: Juni 2018 
Using Ticking Off Items Technique In The Teaching Listening Skill At Elementary Student

the required conditions previously mentioned. In curriculum 2013, English instruction is introduce as an extra-curricular, it means that English is not falling within the scope of the regular curriculum or it takes place outside the normal school time table. But there are some of schools still include the English instruction at elementary schools because it is considered very important and its success has been proved during the implementation of KBK 2004 and KTSP (2012). Yulia (2017) in her research regards the effectiveness of English subject at The Elementary Teacher English Program (PGSD) towards the student's sureness and motivation in English Instruction at Elementary School state that PGSD`s students still have willingness to learn how to teach English to elementary student. One of the mentor teacher say that many of university students are asked to teach English as an extra-curricular at Elementary school.

Commonly vocabulary and pronunciation material is the first priority at elementary school level besides reading and writing. But unfortunately teaching and learning in listening skill is lack of attention. Listening English foreign language activity can be said as foundation in English communication. The objective of teaching and learning listening skills for elementary students is giving comprehension and basic listening skill. In the teaching listening, it is forbidden to test the student how far they can listen a conversation well.

Cahyono (in Annisa, 2012) states that there are three chances of successful in English instruction program. Firstly, the program will be success if the teacher have good capability in pronunciation. Secondly, having the syllabi, good materials and quality teacher, the variation of teaching method. Last, if the focus of teaching and learning are grammatical competence, thus it should be understood and applying communicative approach.

Student of elementary school have different characteristics from adults (learn, behave and think). Some of elementary schools does not have teacher who take English major. Teacher have essential role for making a good atmosphere. Underwood (1993b) states that The teacher`s skills influence very much the student's attitude towards learning. Annisa (2012) states that teacher have to become context -sensitive teachers. It means that the teacher should do context analysis. He / she should now the condition in the class before selecting the method which will be applied. The creative teacher should be able to have motivational and stimulation technique that found to be effective in classroom. 
Using Ticking Off Items Technique In The Teaching Listening Skill At Elementary Student

The important question that should be answered is : how do teacher teach listening without tape recorder? Actually the activity of teaching listening must not rely on cassette and tape recorder. A teacher`s talk could be a teaching material, somehow the teacher must have good pronounciation. In addition, Gusyarani (2010) states that teacher must set the teaching and learning well (pre listening-stage listening-post listening). Moreover, in this study, the writer tries to promote ticking off Items Technique in the teaching listening skill for elementary students

\section{DISCUSSION}

\section{First Language Acquisition (L1) and Second Language Acquisition (L2)}

Language Acquisition is the process mastery of language used by children naturally when she/he learns their first language. It is a subconscious process, in which the learners are the result is also subconscious, children don't aware that they are acquiring a language, they just able to use it, responsible for initiating speech and focus the meaning of utterances. Listening skill in language acquisition is helping people to communicate each other without difficulty. It means that a person who have good in listening in a particular language may not have basic problems in communication with others and can understand what is communicated.

Second language acquisition (L2) refers to any language acquire in addition to a person`s first language. Researchers have found a common sequence of acquisition. According to Gass and Selingker (1994) second language acquisition is learning of another language after the native language has been learned. Sometimes the term refers to the learning of a third or fourth language. The important aspect is that term refers to the learning of a language after the learning of the native language. Second or foreign Language acquisition plays more important role than listening

Below is a figure of Prism Model which is proposed by Collier and Thomas (2007). This model includes first language (L1) and the second language (L2). The academic development, cognitive development and language development, as well as social cultural processes that impact language learning positively and negatively. At school, students acquire second language are influenced by social and cultural process 


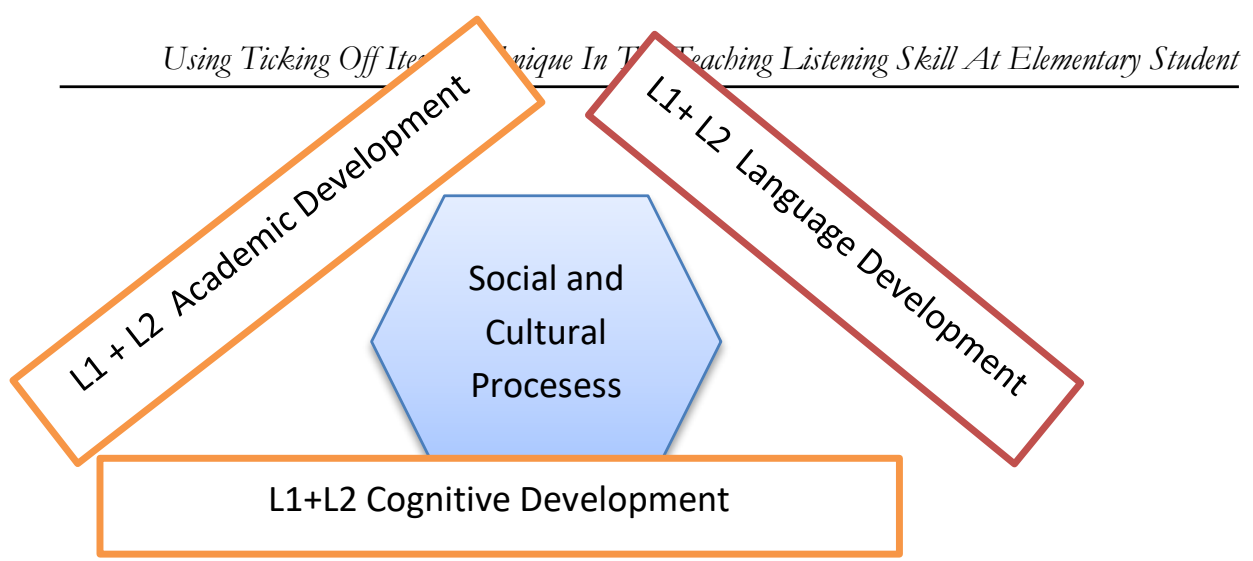

Figure 1. Language Acquisition for school : The Prism Model (Collier \& Thomas, 2007)

Some factors that strongly influence the student's language acquisition within the socio cultural are; all of the surrounding social and cultural process that occur in our life in the past, present and future at home, school, community and larger society. Besides that, students variable such as self esteem, anxiety, and affective factors also can influence student language acquisition. Student's achievement at school can be influenced by instructional environment because the group, community and social pattern such as prejudice and discrimination can express toward a group of people and individual.

\section{Hearing and Listening}

Listening is the ability to accurately receive and interpret messages in the communication process. Effective Listening requires concentration and the use of your other senses-not just hearing the words spoken. Listening is not the same as hearing and in order to listen effectively you need to use more than just your ears .

According to Underwood (1993b) claimes that listening is the activity of paying attention to and trying to get meaning from something we hear. Physiologically, hearing is a process in which sound waves entering the outer ear and transmitted to the ear-drum, converted into mechanical vibrations in the middle ear into nerve impulses that travel to the brain. While the psychological process of listening begins with someone's awareness of and attention to sounds or speech patterns, proceeds through identification and recognition of specific auditory signals, and ends in comprehension. In line, Linse (2005) states that hearing 
Using Ticking Off Items Technique In The Teaching Listening Skill At Elementary Student

refers to the actual perception and processing of sound. In order to be able to listen in class, children need to be able to hear. Oxford (1993: 206) says that listening should include "perception of sounds, comprehension of meaning-bearing words, phrases, clauses, sentences and connected discourses". In sum, listening is a complex process of interpretation in which listeners match how the language is used and what they hear with situation of speaking.

\section{Listening Skill for Young Learner}

Listening skill is foundation for other skills. Children should develop their listening skill when learn foreign language. By developing good listening skills, children able to match the sound with corresponding symbols when they decode words. By listening, children are preparing to imitate the sounds when they speak. In addition, listening skills can lay foundation for reading instruction because by developing good listening skill, children match the sounds with corresponding symbols (decode words) (Scott \& Ytreberg :2006). In line with Linse (2005) says that listening comprehension skills can prepare children to develop reading comprehension skills.

Table 1. Listening Skills for Young Learner

Skill How it prepares for reading

\begin{tabular}{cc}
\hline $\begin{array}{c}\text { Listen to and follow } \\
\text { instruction such as take } \\
\text { out your pencil and } \\
\text { your activity green } \\
\text { book }\end{array}$ & $\begin{array}{c}\text { Prepares children for a variety of academic } \\
\text { task }\end{array}$ \\
\hline $\begin{array}{c}\text { Can follow an oral } \\
\text { sequence of events }\end{array}$ & Prepares children to comprehend the story \\
such as Lucy went to \\
the refrigerator and \\
took out some milk \\
\hline $\begin{array}{c}\text { Can listen attentively to } \\
\text { stories }\end{array}$ \\
\end{tabular}

Madrosatuna: Jurnal Pendidikan Guru Madrasah Ibtidaiyah 1(1) (2018) 1-11 
Using Ticking Off Items Technique In The Teaching Listening Skill At Elementary Student

\begin{tabular}{cc}
\hline $\begin{array}{c}\text { Can discriminate } \\
\text { between sound such as } \\
/ \mathrm{b} / \text { and /p/ }\end{array}$ & $\begin{array}{c}\text { Prepares children to decode words/ help to } \\
\text { prepares children for phonic instruction }\end{array}$ \\
\hline $\begin{array}{c}\text { Can comprehend a } \\
\text { story that has been } \\
\text { read and/or told }\end{array}$ & Prepares children to comprehend the story \\
\hline $\begin{array}{c}\text { Can identify rhyming } \\
\text { sounds }\end{array}$ & $\begin{array}{c}\text { Prepares children to decode words/ help to } \\
\text { prepares children for phonic instruction }\end{array}$ \\
& \\
\hline $\begin{array}{c}\text { Can segment words } \\
\text { into syllables such as } \\
\text { ap-ple or din-ner }\end{array}$ & $\begin{array}{c}\text { Prepares children to decode words/ help to } \\
\text { prepares children for phonic instruction }\end{array}$ \\
\hline
\end{tabular}

\section{Teaching Listening in Class}

The teaching of listening plays important role in every EFL teachers especially EYL teachers. According to Harmer (1998:98) said the objective of teaching listening are ; first to get students to listen to differenet varieties and accents of English, second, to help students to acquire language subsconsciously, and last, to help students be better listener. Meanwhile Kasbolah (2007:54) said that the ojectives of teaching listening for young learner are listening the instructions, doing to do something, getting information, acquiring message, news, and stories orally.

Teaching listening to children should make fun and varieties. Children who learn second or foreign language learning require time and psychological area. Every students have difference characteristic. Teacher have to know these difference in teaching and learning. There are some characteristic of student. First, children`s have different in experience and attitude. The more teacher gain or expose student`s unique experience the more relevant learning becomes. Second, children are different in level attainment and interest. Some student have difficulty in learning foreign language. The difficulty will vary. Every student have different learning style (Sugito, 2007)

\section{The Rules for Teaching Listening}


a. Improving student's confidence. Teacher must understand their condition that every students are not always comprehend every words that teacher's explain and pronounce

b. Giving the explanation why student must listen. Make sure they know the beneficent and the purpose of listening skill

c. Helping the children for developing some listening strategies. "smart guessing" is one of good strategy to be applied in the class. Children use their own background knowledge for knowing something that there are not certain sure.

d. Setting the steps of teaching and learning well. Teacher should apply pre listening, listening stage and post listening.

e. Listening is not depend on cassette and tape recorder. Most of listening material is teacher`s talk.

There are some techniques for teaching listening in the classroom ;

1. Listening for perception. The main objective of this technique is train student to perceive the different sounds correctly, sound combinations and stress and intonation of the foreign language

a. At word level (oral Activities, reading and writing activities)

b. At sentence level (oral activities, reading and writing activities

2. Listening for comprehension. This technique involve other language skills and imaginative or logical thought.

a. Listening and making no response (following a written text, listening to a familiar text, listening aided by visuals, informal teacher`s talk)

b. Listening and making short responses

c. (obeying instruction, ticking off items, true/false exercise, pictures, maps)

d. Listening and making longer responses (repetition and dictation, translation, filling gaps)

e. Listening as a basic for study and discussion (problem solving, jigsaw listening)

Listening activities in the classroom can be divided into three stages, the activities are below

a. Pre Listening-----activities when teacher help your students for preparing what they will hear. The purpose of pre listening activity are: arousing interest, activating prior knowledge, building vocabulary knowledge, and predicting the content. In pre listening stage you can discuss the topic of conversation, give students information about the context, for example who is talking, where there are, help to find them

Madrosatuna: Jurnal Pendidikan Guru Madrasah Ibtidaiyah 1(1) (2018) 1-11 
unknown vocabulary, give them some predictions questions about the topic, teacher should give the sureness what the students have to do and make sure your students understand the reason doing the activity for example to practice listening to native speaker.

b. Listening Stage----Activities when teacher give type of task for example answering questions (comprehension, multiple choice, true or false), completing something ( a form, grid, chart, picture), following direction on a map, matching what is being said with a set a pictures, and doing something when students response what they hear for example, drawing and moving (stand up, sit down). The purposes of while listening activities is to help learners improve the skills of understanding the messages from spoken language.

c. Post listening---- is teaching step the teacher uses after presenting the listening text. Activities when the teacher check students understanding of what they have been listening to, give feedback For example speaking activities, writing activities and pronunciation activities

\section{Teaching Procedure of Ticking off Items Technique}

\section{Pre- Listening Activities}

a. The teacher prepares her headings, write in the appropiate colums the items she is going to mention. She may also note the number of each column, to save counting later, and a suggested context. For example

Food

Drink

cake tea

cheese coffe

biscuits milk

bread water

butter

5

4

b. Give clear instruction goal of the lesson in order students understand what they are going to do in class.

\section{Listening Stage Activities}

Madrosatuna: Jurnal Pendidikan Guru Madrasah Ibtidaiyah 1(1) (2018) 1-11 
a. The teacher then call out the names of the items in random order. For example cake, tea,cheese, coffe, biscuits, milk, bread, water, butter

b. The students hear, identify and put a tick in the right column.

c. The result would like this

$\begin{array}{ll}\text { Food } & \text { Drink } \\ \sqrt{ } & \sqrt{ } \\ \sqrt{ } & \sqrt{ } \\ \sqrt{ } & \sqrt{ } \\ \sqrt{ } & \sqrt{ } \\ \sqrt{ } & \end{array}$

\section{Post Listening Activities}

Teacher feedback consist simply of checking that the students have the right number of ticks in each column. In slightly more advanced form, the items can be applied in a coherent passage of discourse:

Good morning, I'd like a cup of coffe please, and a small piece of cake. My husband will have a cup a tea with some biscuits and cheese. And could you bring a glass of milk for my little girl, with a slice of bread and butter? And if it isn t too much trouble-a bowl of water for the dog.

The result of student-response is the same type as the above:

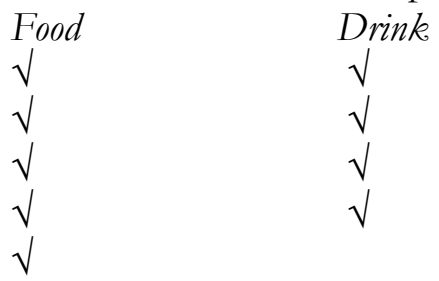

Teaching listening to young learner in the classroom is not just talking about how to prepare recording. Since listening skill is important to learned and mastered by the students, it is necessary to teach it in simple way for young learner. By implementing this technique, the students may not get bored, build up confidence and feel attracted. The teacher can improvise using vocabulary recently learnt in class. Suggested topic for young learner are : animals, the house, the body, colours, profession. Besides, the preparation of this technique is quick and easy. The teacher may given feed back in form of a quick oral check such as : Good...does everyone agree?....., what was your answer?...., anyone have anything different? 
Using Ticking Off Items Technique In The Teaching Listening Skill At Elementary Student

\section{CONCLUSION}

Listening is important for young learner to learn foreign language because it is a foundation to master other skills. It is different from adult in which reading is the first skill to mastered. Teacher need to be qualified and linguistically proficient. Teacher should be more creative teaching listening to young learner, in other the students are fun and interesting. She or he should adapt or adopt varied approaches. So, they will be appropiate for young learners. Somehow, listening is a complex process. Teacher should not rely on tape recorder to teach listening.. The teacher talk can be a teaching material. Consequently, teacher should have good pronounciation.

\section{REFERENCES}

Annisa, Fitri. (2012). Teaching English for Elementary School. Bandung: Grafika Wahana Karya

Gas, Susan M \& Selinker, Larry. (1994). Second Language Acquisition. An Introductory Course. New Jersey: Lawrence Erlbaum Associates, Inc.

Gusrayani, Diah. (2010). Teaching English to Young Learners. Sebuab Telaah Konsep Bahasa Inggris Kepada Anak-anak. Bandung :UPI press

Linse, Caroline T. (2005). Practical English Language Teaching. Young Learners.

New York: Mc Graw-Hill ESL/ELT Oxford, R.L. 1993. Research Update on Teaching

L2 Listening. System, 21 (2): 205-211.

Rachmajanti, Sri. (2008). Impact of English Instruction at The Elementary Schools. TEFLIN Journal, 19(2), 160-183

Scott, Wendy A., \& Ytreberg, Listbeth. (2006). Teaching English To Children. New York: Longman

Sugito. (2007). Teaching Listening Comprehension to the Fourth Graders of Elementary School Students by Using Total Physical Response Method, A Case of The Fourth Graders of SDN Jinggotan Kembang Jepara in the Academic Year of 2004/2005. Unpublished Skipsi

Suyanto, Kasihani K.E. (2007). English For Young Learners. Melejitkan Potensi Anak. Melalui English Class yang Fun, Asyik, dan Menarik.Jakarta :PT Bumi Aksara.

Underwood, M. (1993). Effective Class Management: A Practical Approach. London and New York: Longman.

Ur, Penny. (1984). Teaching Listening Comprehension. Cambridge: Cambridge University Press. 
Using Ticking Off Items Technique In The Teaching Listening Skill At Elementary Student

Yulia, Yuyun. (2017). Kebutuhan Mahasiswa PGSD Terhadap Mata Kuliah Bahasa Inggris. Trihayu: Jurnal Pendidikan ke-SD-an, 3(3), 173-179. .........(2016). Teaching Speaking and Listening In Primary School. Modul 3:TMT 224. Florida State University,

http://pdf.usaid.gov/pdf docs/PA00MMCZ.pdf was accessed on March 4, 2018 